Зоранчо Малинов

\title{
ВИСОКООБРАЗОВНАТА ДЕЈНОСТ ВО ИНСТИТУТОТ ЗА ФОЛКЛОР „МАРКО ЦЕПЕНКОВ“ ВО ПЕРИОДОТ 2008 - 2019 ГОДИНА
}

\begin{abstract}
Апстракт: Освен на полето на: истражувањето, архивирањето, публикувањето и популаризирањето на македонската традиционална култура, Институтот за фолклор од 2008 год. е регистриран и за високообразовна дејност, односно се има стекнато со акредитација за организирање студии од втор (постдипломски) и трет циклус (докторски) студии. На тој начин на научниот кадар во Институтот му беше овозможено да го искористи својот потенцијал и на полето на високообразовната дејност, односно можноста стекнатото знаење и искуство од своите децениски истражувања да има можност да го пренесува и на помладите генерации.

Во изминатите 10-ина години со научната титула магистер по фолклористика се имаат стекнато вкупно 12 кандидати (9 според старата студиска програма и 3 според новата) и се промовирани 12 доктори по фолклористика.
\end{abstract}

Клучни зборови: високообразовна дејност, Институт за фолклор, фолклористика, студии од втор и од трет циклус.

Институтот за фолклор „Марко Цепенков“ од Скопје е јавна научна установа формирана во далечната 1950 година со Одлука на Владата на тогашна Народна Република Македонија, како самостојна научна институција од посебен национален интерес.

Првичното име, при основањето на Институтот, е Фолклорен институт на НР Македонија, во 1962 год. се преименува во Институт за фолклор, а од 1979 година во својот назив го носи и името на прилично плодниот собирач на македонски фолклорни и етнографски материјали од крајот на 19 век, Марко Цепенков.

Во своето речиси седумдецениско постоење оваа научна институција има постигнато солидни резултати на полето на: истражувањето, архивирањето и публикувањето на македонската традиционална култура, но и на народната култура на останатите народи што живеат во државава. Во овој контекст е доволно само да ги споменеме реномираниот Меѓународен симпозиум за балкански фолклор, кој вообичаено, до 2008 година, се одржуваше биенално во Охрид, како и стручното научно списание „Македонски фолклор“, кое редовно се публикува од 1968 година и досега се испечатени 75 броја.

Во областа на издавачката дејност, Институтот за фолклор може да се пофали и со публикуваните над 150-ина книги од сите области на истражувањето на народната култура: народната проза и поезија, обичаите, народните музички инструменти, вокалната традиција, ората, народните носии, традиционалната архитектура итн. 
Институтот за фолклор, во својата организациска структура, во актуелниов момент (2019 год.) има пет научноистражувачки оддели, кои низ децениите наназад носеле и поинакви називи, а денес се именувани како: 1 . Оддел за народна литература и етнотеатрологија (порано: Оддел за народна литература), 2. Етнолошки оддел (порано: Оддел за народни обичаи и игри), 3. Оддел за традиционални уметности и архитектура (порано: Оддел за народна орнаментика, па Оддел за материјална култура), 4. Оддел за етномузикологија и етнокореологија (порано: Оддел за народна музика и ора) и 5. Оддел за истражување на фолклорот и етнологијата на другите народи што живеат во Република Македонија (порано: Оддел за истражување на фолклорот на народностите), во кој работат научни работници, коишто ја истражуваат народната култура на: Албанците, Турците, Власите и Ромите.

Во оваа реномирана научна институција досега свој белег имаат оставено над 60-ина реномирани македонски истражувачи од областа на: фолклористиката, етнологијата, етномузикологијата и другите сродни научни дисциплини, а во оваа пригода ќе издвоиме некои од нив, кои дадоа свој придонес не само на македонската научна мисла, туку и пошироко во балкански рамки, како што се на пример, фолклористите: Блаже Ристовски, Лазо Каровски, Цветанка Органџиева, Танас Вражиновски, Александра Попвасилева, Блаже Петровски, Татјана Каличанин, Севим Пиличкова, Боне Величковски, Клеанти Ановска, Ермис Лафазановски, Лидија СтојановиќЛафазановска, Катерина Петровска-Кузманова, Изаим Муртезани; етнолозите: Ангелина Крстева, Галаба Паликрушева, Ѓорѓ Здравев, Анета Светиева, Трајко Петровски, Весна Петреска, Зоранчо Малинов; етномузиколозите: Живко Фирфов, Ганчо Пајтонџиев, Ѓорѓи Ѓорѓиев, Боривоје Џимревски, Трпко Бицевски, Родна Величковска; етнокореологот Михаило Димовски и др. ${ }^{1}$

Институтот за фолклор од 2006 година е препознатлив и на полето на заштитата на нематеријалното културно наследство, благодарение на сообразеноста со Законот за заштита на културното наследство, која се одвива во согласност со препораките на светската организација за образование, наука и култура - УНЕСКО. Институтот досега има изготвено 60-ина елаборати за валоризација и ревалоризација на нематеријални добра, од кои, пет се наоѓаат и на листите на УНЕСКО за нематеријално културно наследство на човештвото: „Чет’рсе - празнувањето на Св. 40 маченици во Штип“ и „Копачката - машко соборно оро од с. Драмче, Пијанец (Делчевско)“ - и двете на репрезентативната листа на нематеријалното културно наследство на

\footnotetext{
1 За историскиот развој на Институтот за фолклор, организацијата на научноистражувачките оддели, како и за вработените научни работници, повеќе информации можат да се добијат во монографиите по повод 30-годишниот и 50годишниот јубилеј од неговото формирање: 30 години Институт за фолклор „Марко Цепенков “, Редакција: д-р Лазо Каровски (претседател), д-р Цветанка Органџиева и Танас Вражиновски, Скопје, 1980, стр, 11-87 и 50 години Институт за фолклор „Марко Цепенков“ - Скопје (1950-2000), подготвила Мирјана Анастасова, Скопје, 2000, стр. 143-151.
} 
човештвото, додека „Гласоечко - машко двогласно пеење од Долни Полог (Тетовско)“ е впишано на листата на нематеријалното културно наследство на човештвото за ургентна заштита. На репрезентативната листа на нематеријалното културно наследство на УНЕСКО се наоѓаат и две културни добра, кои се номинирани од Република Македонија, заедно со уште неколку држави, и тоа: „Мартинки - културни практики поврзани со 1-ви март“, кое е номинирано заедно со Романија, Молдавија и Бугарија, и „Х'д’рлез пролетно прославување“, кое е номинирано заедно со Турција. ${ }^{2}$

Но, на сите тие успеси на оваа реномирана научна институција на полето на истражувањето на традиционалната култура како да им недостасуваше верификација и од аспект на високообразовната дејност, со оглед на фактот што некои од вработените научни работници во Институтот веќе се имаа стекнато со извесно искуство во изведувањето на настава по соодветни предмети од своите области на истражување на додипломските или на постдпипломските студии на некои од универзитетите во државава. ${ }^{3}$ Во прилог на желбите на вработените научни работници во Институтот, за започнување со едукација на кадар од областа на фолклористиката, им одеа и законските одредби со кои, на научните институти, им се овозможуваше организирање на постдипломски студии од соодветната научна област и на стекнување со научната титула доктор на науки на кандидатите што успешно ќе ја одбранат својата докторска дисертација. Оваа можност, неколку години претходно, благодарение на законските прописи што ги регулираа високообразовната и научноистражувачката дејност, веќе ја имаше искористено Институтот за национална историја, уште во академската 1998/1999 год., а со подготовки за акредитација на студиските програми во рамките на своите дејности беа започнати и останатите сродни научни

\footnotetext{
2 Повеќе информации за овие нематеријални културни добра, кои се наоѓаат на листите на нематеријалното културно наследство на човештвото можат да се добијат на веб-страницата на Институтот за фолклор „Марко Цепенков“: http://ifmc.ukim.mk/index.php, а оттаму со линкови се достапни и официјалните вебстраници на секое од овие нематеријални добра, кои се поставени на официјалната веб-страница на УНЕСКО за нематеријалното културно наследство.

${ }^{3}$ Во периодот кога се аплицираше за акредитација на студиите по фолклористика, како наставници по соодветни предмети од областа на: фолклористиката, етнологијата, етномузикологијата и културната антропологија на разни факултети на неколку универзитети во земјава беа ангажирани: д-р Ермис Лафазановски, д-р Весна Петреска, д-р Лидија Стојановиќ-Лафазановска, д-р Изаим Муртезани, д-р Зоранчо Малинов и д-р Родна Величковска. Поконкретно за ангажманот на споменативе научни работници, како наставници на соодветните високообразовни институции, може да се погледне на официјалната веб-страница на Институтот за фолклор „Марко Цепенков“: ifmc.ukim.mk, каде што секој од вработените од редот на научните работници има презентирано свои биографски податоци, како и во делот кој ги презентира информациите за високообразовната дејност, односно студиите од втор и од трет циклус.
} 
институти: Институтот за македонски јазик „Крсте Мисирков“ - Скопје и Институтот за македонска литература. ${ }^{4}$

Конечно, започнувајќ́ од академската 2008/2009 година, на Институтот за фолклор „Марко Цепенков“, освен со примарната научноистражувачка дејност, му е овозможено да извршува активности и од доменот на високообразовната дејност. Имено, благодарение на предлогпроектот за организирање на постдипломски (магистерски) и докторски студии што го изготви д-р Боне Величковски, како и со соодветните одлуки донесени од страна на надлежните тела на Институтот за фолклор „Марко Цепенков“" и Универзитетот „Св. Кирил и Методиј“, тогашниот Одбор за акредитација на високото образование со Решение бр. Сл. 12 од 26.2.2008 год. му овозможи на Институтот за фолклор за првпат во својата историја да се јави во улога на организатор на постдипломски (магистерски) студии и на докторски студии по фолклористика.

Акредитацијата на студиската програма на постдипломските студии по фолклористика од 2008 год. се однесуваше на 4-семестрални (двегодишни) студии, со вкупно 120 кредити според ЕКТС, така што шесте задолжителни и трите изборни предмети обезбедуваа вкупно 90 ЕКТС, а одбраната на магистерскиот труд - 30 ЕКТС. Задолжителни беа предметите: светска фолклористика, балканска фолклористика, методологија на фолклористичката наука, духовна и материјална култура, теренска фолклористика и странски јазик, а како изборни беа понудени 20-ина предмети, од кои, студентот требаше да одбере три според својот афинитет, кои би биле компатибилни со темата на магистерскиот труд.

Така, според двегодишната (4-семестралната) студиска програма, од вкупно запишаните 12 студенти, магистерските студии успешно ги завршија 9 студенти, кои се стекнаа со научната титула магистер по фолклористика:

1. Ермаљ Мехмети (тема на магистерскиот труд: „Полифоното пеење кај Албанците во Република Македонија, со посебен осврт на Преспанскиот Регион“, ментор: проф. д-р Реџеп Муниши);

2. Џенгис Ибрахим (тема: „Народниот музички инструмент баглама кај Турците во Македонија“, ментор: проф. д-р Родна Величковска);

3. Тимко Чичаковски (тема: „Чалгиската традиција во Берово“, ментор: проф. д-р Родна Величковска);

\footnotetext{
${ }^{4}$ Ова беше овозможено со член 53 од Законот за насоченото образование од 1985 год. (Сл. весник на СРМ бр. 16/85) и член 11 од Законот за научно-истражувачката дејност (Сл. весник на РМ бр. 13/1996), па така, од сродните научни институти ова право најпрвин го искористи Иститутот за национална историја во 1998 год., а потоа, во 2008 година, со донесувањето на Законот за високото образование (Сл. весник на РМ бр. 35/2008) и Законот за научно-истражувачката дејност (Сл. весник на РМ бр. 46/2008), речиси паралелно со Институтот за фолклор, со соодветни акредитации, се стекнаа и Институтот за литература и Институтот за македонски јазик „Крсте Мисирков“ - Скопје. Сите овие четири институти имаат статус на придружни членки на Универзитетот „Св. Кирил и Методиј“ во Скопје и со по еден свој претставник се застапени во Сенатот на УКИМ.
} 
4. Сашо Митев (тема: „Народните музички инструменти и инструменталната традиција во Струмичко-радовишкиот Регион“, ментор: проф. д-р Родна Величковска);

5. Марко Петрушевски (тема: „Психоаналитичката фолклористика на Алан Дандес“, ментор: проф. д-р Лидија Стојановиќ-Лафазановска);

6. Рини Усеини (тема: „Албанските народни носии во Струшко“, ментор: проф. д-р Изаим Муртезани);

7. Трајан Ристовски (тема: „Традициски верувања и обредна пракса околу раѓањето кај Овчеполците“, ментор: проф. д-р Зоранчо Малинов);

8. Зоран Џорлев (тема: „Ороводните песни како дел од македонската обредно-пејачка традиција“, ментор: проф. д-р Родна Величковска);

9. Антонија Гугинска-Јорданоска (тема: „Традиционалната текстилна орнаментика во Скопска Блатија“, ментор: доц. д-р Јасминка Ристовска Пиличкова).

Но, со оглед на фактот што во меѓувреме се донесоа нови законски регулативи во однос на акредитациите за студиите од втор циклус, односно на постдипломските (магистерски) студии, Институтот за фолклор, врз основа на предлог-проектот изработен од раководителот на постдипломските (магистерски) студии, д-р Весна Петреска ${ }^{5}$, во мај 2013 год. усвои нова студиска програма, со која се предвидува студиите од втор циклус да бидат двосеместрални (едногодишни), а како новитет се јавува и можноста за студирање на еден од двата предвидени модули: Интермедијални студии по фолклористика и Фолклористички истражувања на културата. И двата модули имаат вкупно по шест предмети, од кои три задолжителни и три изборни, со вкупно 30 ЕКТС, додека со одбраната на магистерскиот труд, кој носи исто така 30 ЕКТС, студентот, со завршувањето на овие студии, се стекнува со вкупно 60 ЕКТС. Структурата на предметите и стекнувањето на кредитите според ЕКТС и на двата модули се исти, со тоа што и двата модули имаат еден заеднички задолжителен предмет: Фолклористика - методи на научно истражување, а останатите два се различни, со тоа што едниот од предметите има идентичен наслов како и самиот модул на студиската програма. Од изборните предмети студентот може да бира од 20-ината предмети што ги нуди Институтот за фолклор, така што, едниот мора да е од понудената листа за соодветниот модул, вториот може да е кој било предмет од целокупната понудена листа на Институтот за фолклор, т.е. од листите на двата модула, а третиот треба да биде избран од понудената листа на изборни предмети на

5 Со самото започнување на постдипломските (магистерските) студии за прв раководител беше избран проф. д-р Ермис Лафазановски; во периодот 2009 - 2011 год. раководител на студиите беше проф. д-р Боне Величковски; во периодот 2011 2012 год. со студиите раководеше проф. д-р Зоранчо Малинов; а од 2012 год. до актуелниов момент раководител на студиите од втор циклус по фолклористика е проф. д-р Весна Петреска. 
УКИМ, каде што се поставени и изборните предмети понудени од Институтот за фолклор. ${ }^{6}$

Вака структурираната студиска програма на студиите од втор циклус по фолклористика се официјализираше со почетокот на академската 2014-2015 год., бидејќи Решението за акредитација на студиската програма, издадено од Одборот за акредитација и евалуација на високото образование (бр. 13-130/2), беше донесено на 30.10.2013 год., а Решението од Министерството за образование и наука за започнување на студиите (бр. 13-869/2) беше издадено на 24.1.2014 год. ${ }^{7}$ По новата, двосеместрална (едногодишна) студиска програма до сега се запишаа вкупно 10 студенти, а студиите ги завршија тројца студенти:

1. Мелита Ивановска (тема: „Обредната пејачка традиција кај Македонците со исламска религија во Долна Река““, ментор: проф. д-р Родна Величковска);

2. Горан Василески (тема: „Женските обредни поворки во Брсјачката етнографска целина“, ментор: проф. д-р Зоранчо Малинов);

3. Ружица Самоковлија-Барух (тема: „Обредноста при воведувањето во статусот жена во македонската традиционална култура“, ментор: проф. др Весна Петреска).

До започнувањето на академската 2019-2020 год., со статус на активни студенти се четворица, кои се во различни фази од студирањето.

Што се однесува до добиената акредитација за докторските студии во 2008 год., таа не го дочека своето вистинско заживување, со оглед на фактот што веднаш по здобивањето со акредитацијата настанаа измени во законската регулатива, бидејќи постоеја извесни недоречености во организирањето на докторските студии, односно студиите од трет циклус, како што подоцна беа наречени. Но, во секој случај оваа акредитација му овозможи на Институтот за фолклор да организира одбрани на докторски дисертации на заинтересираните кандидати од областа на фолклористиката, што беше овозможено според законските регулативи што дозволуваа стекнување со научната титула доктор на науки само со пишување и одбрана на докторска дисертација. На тој начин во Институтот за фолклор успешно беа одбранети 12 докторски дисертации, а ректорите на Универзитетот „Св. Кирил и Методиј“ во периодот од 2010 до 2018 год. ги промовираа следниве доктори по фолклористика:

\footnotetext{
6 Подетаљни информации за студиската програма на студиите од втор циклус постдипломски академски студии по Фолклористика можат да се проследат на официјалната веб-страница на Институтот:

http://ifmc.ukim.mk/images/PDF/StudiskaprogramaFolkloristika-elaborat-za-vtor-ciklusstudii-31-05-2013.pdf

7 Повеќе информации за целата постапка да се види во документот Извештај за самоевалуација на институцијата и студиската програма по Фолклористика на ИФМЦ, објавен на официјалната веб-страница на Институтот:

http://ifmc.ukim.mk/images/PDF/studii/Samoevaluacija-2017.pdf.
} 
1. Марија Кукубајска (тема на докторската дисертација: „Смртта и вечноста во народните приказни од САД и од Македонија“, ментор: проф. др Ермис Лафазановски);

2. Лидија Чуковска-Робева (тема: „Ерминиите и македонската зографска традиција“, ментор: проф. д-р Донка Барџиева-Трајковска);

3. Благица Хаџи-Јовановска (тема: „Религиозните мотиви во македонската народна поезија“, ментор: проф. д-р Лидија СтојановиќЛафазановска);

4. Етхем Бајмак (тема: „Народните преданија кај Турците од Косово и од Македонија“);

5. Јасминка Ристовска-Пиличкова (тема: „Македонската традиционална текстилна орнаментика - класификација, типологија и семиотика на ликовните елементи“, ментор: проф. д-р Никос Чаусидис);

6. Велика Стојкова-Серафимовска (тема: „Македонската вокална музичка традиција во процесот на општествената транзиција од 80-тите години на минатиот век до денес“, ментор: проф. д-р Родна Величковска);

7. Гоце Гавриловски (тема: „Фолклорот и неговата уметничка транспозиција во дел од симфониското творештво кај македонските композитори“, ментор: проф. д-р Родна Величковска);

8. Гордана Вренцоска (тема: „Македонски визуелен идентитет: дизајнот како можност за еволуција на традициите од визуелното културно наследство“, ментор: проф. д-р Антоанела Петковска);

9. Стојанка Манева-Чупоска (тема: „Естетските и структуралните особености на македонските народни носии, со посебен осврт на мијачката носија и нивните трансформации во современиот моден дизајн“, ментор: проф. д-р Зоранчо Малинов);

10. Владимир Јаневски (тема: „Етнокореолошка класификација на ората во Македонија“, ментор: проф. д-р Родна Величковска);

11. Есмије Весели (тема: „Фолклорните елементи во канонот на Лека Дукаѓини“, ментор: проф. д-р Изаим Муртезани);

12. Беким Рамадани (тема:,Развојните патишта на албанскиот музички фолклор во Тетово и Тетовско“, ментор: проф. д-р Родна Величковска).

Согледувајќи ја потребата од нова акредитација за студиите од трет циклус (докторски студии) по фолклористика, Институтот за фолклор во 2017 год. донесе одлука за прифаќање на предлог-проектот (елаборат) што го изготви проф. д-р Лидија Стојановиќ-Лафазановска, која подоцна беше и избрана за раководител на докторските студии по фолклористика. Решението од одборот за акредитација и евалуација на високото образование беше донесено на 23.11.2017 год. (бр. 1409-163/2), а Решението за почеток со работа на студиската програма од трет циклус по фолклористика МОН го издаде во јануари 2018 год. (УП1 бр. 14-145).

Студиската програма од трет циклус (докторски студии) по фолклористика има два модули: Рефлексивна фолклористика и Апликативна фолклористика, кои имаат иста структура на предметите, според бројот на задолжителните и на изборните предмети, како и останатите активности што 
треба да ги реализираат студентите, што впрочем е регулирано и со законските акти и со правилниците на Универзитетот „Св. Кирил и Методиј“. Вкупниот број кредити што се стекнуваат со завршувањето на студиите од трет циклус по фолклористика изнесува 180 кредити според ЕКТС, кои се распоредени во шесте семестри, колку што траат студиите. ${ }^{8}$

По објавувањето на Конкурсот на УКИМ за академската 2018-2019 год., Институтот за фолклор ги доби и првите студенти на студиите од трет циклус, така што на редовниот упис во октомври 2018 год, се запишаа тројца студенти, а на дополнителниот во јануари 2019 год. се запиша уште еден кандидат. Со оглед на тоа што еден од кандидатите имаше завршено 4семестрални магистерски студии по фолклористика (120 ЕКТС), според тогаш актуелниот Правилник на УКИМ за студирање на трет циклус (докторски студии) нему му беше овозможено директно да се запише во третиот семестар и да биде ослободен од полагањето на предвидените испити во првите два семестри, а наскоро потоа можеше да пријави и тема на докторската дисертација.

Со стартувањето на докторските студии, односно студиите од трет циклус по фолклористика, конечно целосно се заокружи интенцијата на научниот кадар во Институтот за фолклор да го искористи својот потенцијал и на полето на високообразовната дејност, односно можноста стекнатото знаење и искуство од своите децениски истражувања да го пренесува и на помладите генерации. Така, освен претходно споменатите научни работници, кои се имаа стекнато со искуство како наставници на некои од универзитетите во земјава 9 , со акредитациите на студиите од втор циклус (магистерски) и од трет циклус (докторски) студии по фолклористика, целиот научен потенцијал на Институтот за фолклор беше мобилизиран и ставен на располагање за потребите на студиите по фолклористика.

Во актуелниов момент, односно со почетокот на академската 2019-2020 год., Институт от за фолклор располага со 8 научни советници, чие звање според Законот за високото образование е еквивалентно на наставно-научното звање редовен професор, 2 виши научни соработници - вонредни професори и 3 научни соработници - доценти. Од осумте научни советници/редовни професори, 5 се имаат стекнато со акредитација за ментор на докторските студии: проф. д-р Родна Величковска, проф. д-р Лидија СтојановиќЛафазановска, проф. д-р Весна Петреска, проф. д-р Катерина ПетровскаКузманова и проф. д-р Зоранчо Малинов.

\footnotetext{
${ }^{8}$ Подетаљни информации за студиската програма по Фолклористика на студиите од трет циклус - докторски студии можат да се проследат на официјалната веб-страница на Институтот:

http://ifmc.ukim.mk/images/PDF/studii/STUDISKA-PROGRAMA-

FOLKLORISTIKAIIIciklus.pdf. Од академската 2019-2020 год. со докторските студии по фолклористика раководи проф. д-р Катерина Петровска-Кузманова.

${ }^{9}$ Во меѓуувреме и дел од помладиот научен кадар, како д-р Актан Аго и д-р Велика Стојкова-Серафимовска се имаа стекнато со искуство како наставници на некои од универзитетите во земјава.
} 
Освен ангажманот на својот научен (и наставен) кадар, Институтот за фолклор, во рамките на постдипломските и на докторските студии, има ангажирано како ментори и членови на комисии за одбрана на магистерски трудови и докторски дисертации и извесен број истакнати научни и наставнонаучни работници од научните и високообразовните установи од земјава и од странство, главно од: Бугарија, Србија, Косово и Босна и Херцеговина.

Што се однесува до самата структура на студентите што се запишуваат на студиите од втор и од трет циклус по фолклористика може да се дојде до заклучок дека добар дел од нив доаѓаат од областа на етномузикологијата, вклучувајќи ги овде како сродни дисциплини и етноорганологијата и етнокореологијата, потоа од областа на етнологијата и од областа на истражувањето на народната литература. Аналогно на нивната квалификација во однос на додипломските, односно магистерските студии, тие најчесто избираат и теми за нивното понатамошно научно усовршување - теми за нивните магистерски трудови, односно нивните докторски дисертации од истата научна дисциплина, иако имаме и неколку случаи кога дипломиран филолог или етнокореолог одбира тема, која е поблиска до етнолошката проблематика. Впрочем, испреплетувањето на научно-истражувачките полиња и области на релација: етнологија - фолклористика или обратно (фолклористика - етнологија), често пати било тема на дискусија и на самите работни тела на Институтот за фолклор, со оглед на фактот што според официјалната класификација на научноистражувачките подрачја, полиња и области, според Меѓународната Фраскатиева класификација (Сл. весник на РМ бр. 103/2010), фолклористиката се класифицира во научноистражувачкото подрачје: Хуманистички науки (шифра: 6), научноистражувачко поле: Етнологија и етногенеза (шифра: 610) и научноистражувачка област: Фолклористика (шифра: 61008), иако според некои други класификации, фолклористиката се класифицира во науката за книжевност.

Во секој случај, фолклористиката сфатена како наука за народната култура нуди доста предизвици за истражувањето на феноменот на народното творештво, за што ни говори и приложениот список на темите на магистерски трудови и докторски дисертации, одбранети на Институтот. Истовремено, Институтот за фолклор „Марко Цепенков“ може да се пофали дека продуцирањето на магистри и на доктори по фолклористика е уникатен случај не само во нашава држава, туку и пошироко во балкански рамки, со оглед на фактот што темите на научните трудови што се одбранети на оваа институција, во странство главно се продуцираат на катедрите по: етнологија, филологија, историја на уметноста или на музичките академии, што впрочем тоа истото целосно се спроведуваше и во нашата држава до акредитацијата на студиските програми по фолклористика што ги организира Институтот за фолклор, започнувајќ́ од академската 2008-2009 година.

Што се однесува, пак, до применливоста на дипломите на завршените магистранди и докторанди по фолклористика на Институтот за фолклор, според нашите сознанија неколку од нив се вклучени во образовниот процес како наставници во средни училишта (ДМБУЦ „Илија Николовски-Луј“), некои се на разни катедри во високообразовни институции (Музичката 
академија и Филолошкиот факултет при УГД Штип, Филолошкиот факултет ДУ во Тетово, Филолошкиот факултет во Приштина, Косово), некои се вработени во научни институти (Институт за фолклор, Институт за духовното и културно наследство на Албанците - Скопје), некои се професионално ангажирани во НУ Ансамбл „Танец“, а некои немаат речиси никакви допирни точки со нивниот професионален ангажман (новинар, службеник и сл.).

На крајот, може да се заклучи дека високообразовната дејност во рамките на ангажираноста на научниот кадар на Институтот за фолклор „Марко Цепенков“ претставува уште еден предизвик во придонесот на развојот на македонската фолклористика, како наука, која ја истражува и ја афирмира традиционалната култура на македонскиот народ, но и на останатите етнички заедници што живеат во државава. Истовремено, создавањето на млади научни кадри од областа на фолклористиката дава гаранции дека оваа наука има перспективи и во иднина, што во секој случај го зголемува и општественото значење на Институтот за фолклор, како јавна научна установа од посебен национален интерес.

\section{ЛИТЕРАТУРА}

30 години Институт за фолклор „Марко Цепенков“, Редакција: д-р Лазо Каровски (претседател), д-р Цветанка Органџиева и Танас Вражиновски, Скопје, 1980.

50 години Институт за фолклор „Марко Цепенков“ - Скопје (1950-2000), подготвила Мирјана Анастасова, Скопје, 2000.

Користени линкови (сите посетени на 24.1.2020)

http://ifmc.ukim.mk

http://ifmc.ukim.mk/index.php

http://ifmc.ukim.mk/images/PDF/StudiskaprogramaFolkloristika-elaborat-za-vtor-

ciklus-studii-31-05-2013.pdf

http://ifmc.ukim.mk/images/PDF/studii/Samoevaluacija-2017.pdf

http://ifmc.ukim.mk/images/PDF/studii/STUDISKA-PROGRAMA-

FOLKLORISTIKAIIIciklus.pdf

Zorancho Malinov

\section{HIGHER EDUCATION ACTIVITY IN THE INSTITUTE OF FOLKLORE "MARKO CEPENKOV" IN THE PERIOD OF 2008-2019}

\section{Summary}

In addition to the field of researching, archiving, publishing and popularizing of Macedonian traditional culture, The Institute of Folklore since 2008 is also registered for higher education activity, that is, it has gained accreditation for organizing studies of second (postgraduate) and third cycle (doctoral) studies. That way, the scientific staff at the institute was enabled to use its potential in the field of higher education activity, that is, the 
opportunity to transfer the knowledge and experience gained from their decades of research to the younger generations. In the past 10 years, 12 candidates have achieved the scientific title of Master of Folklore ( 9 according to the old study program and 3 according to the new) and 12 folklore doctors are promoted. 